\title{
Insulin resistance and increased pancreatic $\beta$-cell proliferation in mice expressing a mutant insulin receptor (P1195L)
}

\author{
J Ogino, K Sakurai, K Yoshiwara, Yoichi Suzuki ${ }^{1}$, N Ishizuka ${ }^{2}$, N Seki ${ }^{3}$, Yoshifumi Suzuki ${ }^{4}$, H Koseki ${ }^{5,6}$, \\ T Shirasawa ${ }^{1}$, N Hashimoto ${ }^{7}$, K Yagui and $Y$ Saito
}

\author{
Department of Clinical Cell Biology, Graduate School of Medicine, Chiba University, 1-8-1 Inohana, Chuo-ku, Chiba 260-8670, Japan \\ ${ }^{1}$ Department of Molecular Gerontology, Tokyo Metropolitan Institute of Gerontology, 35-2 Sakae-cho, Itabashi-ku, Tokyo 173-0015, Japan \\ ${ }^{2}$ Translational Research Center, Kyoto University Hospital, 54 Kawahara-cho, Shogoin, Sakyo-ku, Kyoto 606-8507, Japan \\ ${ }^{3}$ Department of Internal Medicine, Social Insurance Funabashi Central Hospital, 6-13-10 Kaijin, Funabashi 273-8556, Japan \\ ${ }^{4}$ Department of Internal Medicine, Matsudo Municipal Hospital, 4005 Kamihongo, Matsudo 271-8511, Japan \\ ${ }^{5}$ Laboratory for Developmental Genetics, Riken Research Center for Allergy and Immunology, 1-7-22 Suehiro-cho, Tsurumi-ku, Yokohama 230-0045, Japan \\ ${ }^{6}$ Department of Molecular Embryology, Graduate School of Medicine, Chiba University, 1-8-1 Inohana, Chuo-ku, Chiba 260-8670, Japan \\ ${ }^{7}$ Department of Diabetes and Metabolic Disease, Asahi General Hospital, I-1136, Asahi 289-2511, Japan \\ (Requests for offprints should be addressed to K Sakurai; Email: sakuraik@faculty.chiba-u.jp)
}

\begin{abstract}
Several mutations of the tyrosine kinase domain of insulin receptor (IR) have been clinically reported to lead insulin resistance and insulin hypersecretion in humans. However, it has not been completely clarified how insulin resistance and pancreatic $\beta$-cell function affect each other under the expression of mutant IR. We investigated the response of pancreatic $\beta$-cells in mice carrying a mutation (P1195L) in the tyrosine kinase domain of IR $\beta$-subunit. Homozygous (Ir $\left.{ }^{\mathrm{P} 1195 \mathrm{~L} / \mathrm{P} 1195 \mathrm{~L}}\right)$ mice showed severe ketoacidosis and died within 2 days after birth, and heterozygous $\left(\right.$ Ir $\left.^{\mathrm{P} 1195 \mathrm{~L} / \mathrm{wt}}\right)$ mice showed normal levels of plasma glucose, but high levels of plasma insulin in the fasted state and after glucose loading, and a reduced response of plasma glucose lowering effect to exogenously administered insulin compared with wild type $\left(I r^{\mathrm{wt} / \mathrm{wt}}\right)$ mice. There were no
\end{abstract}

differences in the insulin receptor substrate (IRS)-2 expression and its phosphorylation levels in the liver between $I r^{\mathrm{P} 1195 \mathrm{~L} / \mathrm{wt}}$ and $I r^{\mathrm{wt} / \mathrm{wt}}$ mice, both before and after insulin injection. This result may indicate that IRS-2 signaling is not changed in $I_{r}^{\mathrm{P} 1195 \mathrm{~L} / \mathrm{wt}}$ mice. The $\beta$-cell mass increased due to the increased numbers of $\beta$-cells in $I_{r}^{\mathrm{P} 1195 \mathrm{~L} / \mathrm{wt}}$ mice. More proliferative $\beta$-cells were observed in $I r^{\mathrm{P} 1195 \mathrm{~L} / \mathrm{wt}}$ mice, but the number of apoptotic $\beta$-cells was almost the same as that in $I r^{\mathrm{wt} / \mathrm{wt}}$ mice, even after streptozotocin treatment. These data suggest that, in $I_{r}^{\mathrm{P} 1195 \mathrm{~L} / \mathrm{wt}}$ mice, normal levels of plasma glucose were maintained due to high levels of plasma insulin resulting from increased numbers of $\beta$-cells, which in turn was due to increased $\beta$-cell proliferation rather than decreased $\beta$-cell apoptosis.

Journal of Endocrinology (2006) 190, 739-747

\section{Introduction}

Type-2 diabetes mellitus is a common metabolic disorder characterized by insulin resistance and deterioration of $\beta$-cell function (Reaven 1988, DeFronzo et al. 1992). Pancreatic $\beta$-cells showed various responses when insulin resistance occurred (Lingohr et al. 2002a). It has been clinically reported that mutation of the insulin receptor (IR) gene causes various forms of insulin resistance, such as overt diabetes, impaired glucose tolerance, or normal glucose tolerance, and such mutation causes normoglycemic patients to show hyperinsulinemia after a glucose tolerance test. The relationship between insulin resistance and the response of pancreatic $\beta$-cells has been investigated using genetically manipulated mice (Bruning et al. 1998, Kulkarni et al. 1999, Michael et al. 2000, Nandi et al. 2004), but the mechanism by which the increase in pancreatic islet mass is induced in the insulin-resistant state and whether this change favors the progression of diabetes has to be elucidated.

To examine the association between insulin resistance and pancreatic $\beta$-cell function under clinically relevant conditions, we have studied a knockin mouse model with a mutant IR. This mouse model has a mutation substituting Leu for Pro at codon 1195 (P1195L) in exon 20 of the murine IR gene, and this mutation is located in the tyrosine kinase domain of the IR $\beta$-subunit and is similar to daf- 2 mutation of Caenorhabditis elegans. These mice have been reported to show longevity and resistance to oxidative stress (Baba et al. 2005). Some mutations of the tyrosine kinase domain of the IR $\beta$-subunit have been reported in an obese insulin-resistant patient with hyperandrogenism, acanthosis nigricans (HAIR-AN), and polycystic ovary syndrome (Kim et al. 1992), but the contribution of these mutations to pancreatic $\beta$-cell function remains unclear. 


\section{Materials and Methods}

\section{Animal procedures}

The creation of IR knockin mice $\left(I^{\mathrm{P} 1195 \mathrm{~L} / \mathrm{wt}}\right)$ has previously been described (Baba et al. 2005). The genotypes were examined by PCR amplification of genomic DNA extracts from tail tips. Heterozygous $\left(I^{\mathrm{P} 1195 \mathrm{~L} / \mathrm{wt}}\right)$ mice were then intercrossed to generate homozygous $\left(\right.$ Ir $\left.^{\mathrm{P} 1195 \mathrm{~L} / \mathrm{P} 1195 \mathrm{~L}}\right)$ ones. The mice were allowed free access to water and laboratory chow (rodent diet CE-2, Clea Japan, Tokyo, Japan) and kept under a $12 \mathrm{~h}$ light: $12 \mathrm{~h}$ darkness cycle. Male mice were used for the characterization of the glucose homeostasis phenotype and pancreatic histology. Animal care and experiments were performed in accordance with the guidelines of Chiba University, Japan.

\section{Blood biochemistry}

Blood glucose, plasma insulin levels, and blood 3-hydroxybutyrate levels were determined using an automatic blood glucose monitor (FreeStyle, Kissei Pharmaceutical Co., Nagano, Japan), a mouse insulin ELISA kit (Shibayagi Co., Gunma, Japan), and an automatic ketone monitor (Sanwa Chemical, Aichi, Japan), respectively. Intraperitoneal glucose tolerance tests (IPGTTs) were performed on mice fasted overnight, using an i.p. glucose injection of $2 \mathrm{~g} / \mathrm{kg}$ body weight. Blood glucose and plasma insulin levels were measured after $0,15,30,60$, and $120 \mathrm{~min}$. Intraperitoneal insulin tolerance tests (ITTs) were performed on randomly fed mice injected with $0.6 \mathrm{U} / \mathrm{kg}$ body weight of human insulin. Blood glucose levels were measured after $0,15,30$, and $60 \mathrm{~min}$.

\section{Immunoprecipitation and Western blotting}

Mice were fasted overnight, and anesthetized with an i.p. injection of sodium pentobarbital. Saline or $10 \mathrm{U}$ of regular insulin were injected into the i.p. cavity. After $5 \mathrm{~min}$, the liver was excised and homogenized in ice-cold lysis buffer containing 1\% Triton X-100, 10\% glycerol, 1\% NP-40, $50 \mathrm{mM}$ HEPES ( $\mathrm{pH} 7 \cdot 4), 10 \mathrm{mM}$ EDTA, $5 \mathrm{mM}$ sodium vanadate, $100 \mathrm{mM} \mathrm{NaF}, 10 \mathrm{mM}$ sodium pyrophosphate, $0.3 \mathrm{mg} / \mathrm{ml}$ phenylmethylsulfonyl fluoride, and a protease inhibitor cocktail (Roche). The insoluble material was removed by centrifugation at $100000 \mathrm{~g}$ using a P55ST rotor (Hitachi) for $60 \mathrm{~min}$ at $4{ }^{\circ} \mathrm{C}$, and equal amounts of the protein were immunoprecipitated using the indicated antibodies, followed by incubation with protein A agarose (Pierce, Rockford, IL, USA) for $12 \mathrm{~h}$ at $4{ }^{\circ} \mathrm{C}$. Anti-IR antibody was obtained from Santa Cruz Biotechnology (Santa Cruz, CA, USA), anti-insulin receptor substrate (IRS)-1, and anti-IRS-2 antibodies were purchased from Upstate Biotechnology (Lake Placid, NY, USA) and anti-phosphotyrosine antibody was obtained from Transduction Laboratories (Lexington, KY, USA). The samples were processed for SDS-PAGE and Western blotting as described previously (Shibasaki et al. 2003).

\section{Immunohistochemical analysis}

Pancreata were removed from wild-type $\left(I^{\mathrm{wt} / \mathrm{wt}}\right)$ and $I^{\mathrm{P} 1195 \mathrm{~L} / \mathrm{wt}}$ mice. The tissues were fixed and embedded in paraffin. Sections of $3 \mu \mathrm{m}$ thickness were prepared at intervals of $100 \mu \mathrm{m}$. Images of all pancreatic islets found in five sections were subjected to immunohistochemical staining with antiinsulin antibody (DAKO Co., Carpinteria, CA, USA), and digitally recorded using a Carl Zeiss Axioskop 2 plus microscope equipped with an AxioCam HRc charge coupled device (CCD) camera (Carl Zeiss Japan, Tokyo, Japan). The total area of the pancreas and the $\beta$-cell area were measured using NIH Image software version 1.6 (National Institutes of Health, Bethesda, MD, USA).

\section{Determination of pancreatic $\beta$-cell proliferation}

To determine the level of $\beta$-cell proliferation, mice at the age of 4 weeks were injected intraperitoneally with $100 \mathrm{mg} / \mathrm{kg}$ BrdU (Cell Proliferation kit, Amersham Pharmacia Biotech, Piscataway, NJ, USA) and killed after $6 \mathrm{~h}$. Pancreata were fixed and embedded in paraffin, stained with anti-BrdU antibody (DAKO) and subsequently with anti-insulin antibody. Images of all pancreatic islets found in five sections from each specimen ( $3 \mu \mathrm{m}$ sections separated by $100 \mu \mathrm{m})$ were digitally recorded using a microscope fitted with a CCD camera. Results are given as the number of $\mathrm{BrdU}$ and insulin double-positive cells expressed as a percentage of the total number of insulin-positive cells. At least 1000 islet $\beta$-cell nuclei were counted in each pancreas (Flier et al. 2001).

\section{Apoptosis studies}

Male mice at the age of 8 weeks were injected daily with streptozotocin $(40 \mathrm{mg} / \mathrm{kg})$ intraperitoneally for 5 consecutive days (Tuttle et al. 2001). Blood glucose levels were measured at the indicated time after streptozotocin injection. On day 15, pancreata were removed. The ApopTag peroxidase in situ detection kit (Intergen, Purchase, NY, USA) was used for measurement of apoptotic cells. Apoptotic $\beta$-cells were detected based on TUNEL and insulin double-staining.

\section{Statistical analysis}

Results are expressed as means \pm s.E.M. Statistical analysis was carried out using unpaired Student's $t$-test, with $P<0 \cdot 05$ considered statistically significant.

\section{Results}

Characteristics of newborn mice with homozygous and heterozygous mutant of $\operatorname{Ir}^{P 1195 \mathrm{~L}}$

$I r^{\mathrm{wt} / \mathrm{wt}}, I r^{\mathrm{P} 1195 \mathrm{~L} / \mathrm{wt}}$, and $I r^{\mathrm{P} 1195 \mathrm{~L} / \mathrm{P} 1195 \mathrm{~L}}$ mice were born in accordance with their Mendelian inheritance. $I_{r}^{\mathrm{P} 1195 \mathrm{~L} / \mathrm{P} 1195 \mathrm{~L}}$ mice had a lower body weight, higher levels of glucose, blood 

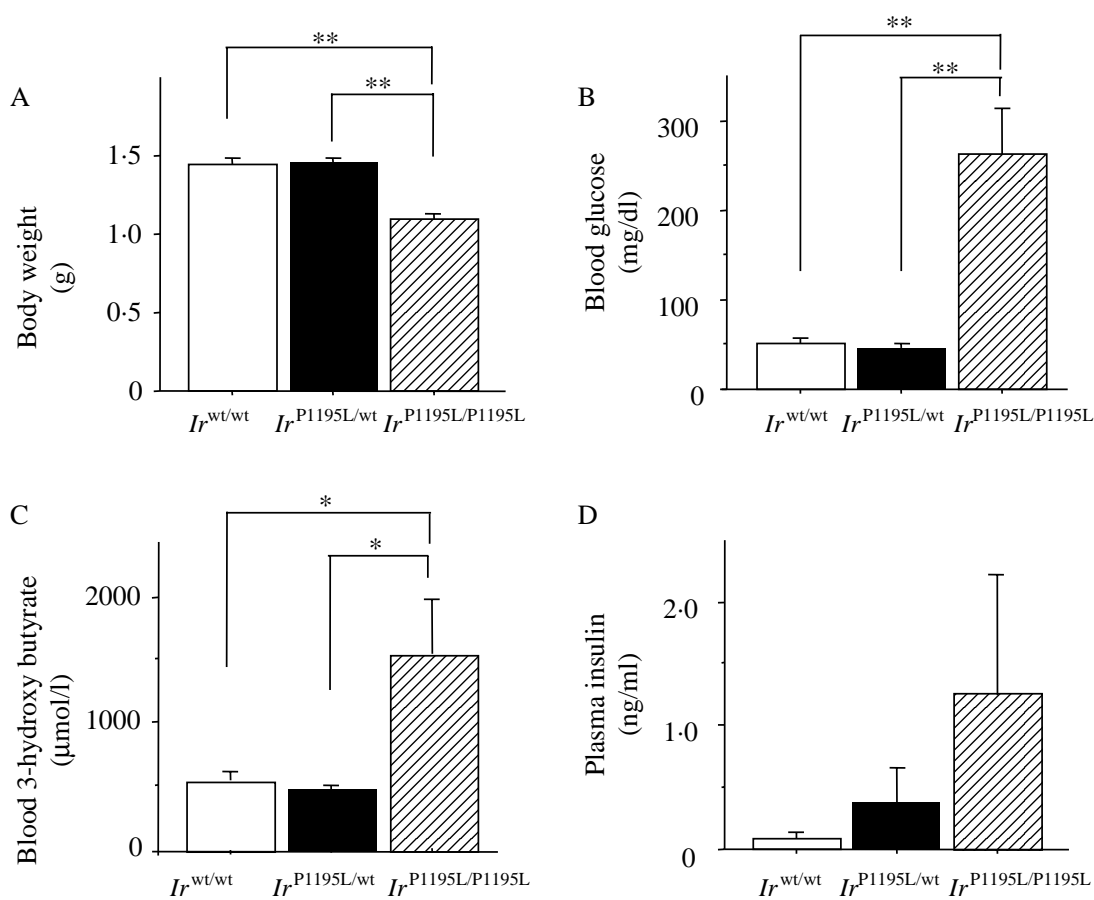

Figure 1 Metabolic characteristics of newborn mice. Body weight (A), blood glucose (B), blood 3-hydroxybutyrate (C), and plasma insulin levels (D) were measured between 24 and $48 \mathrm{~h}$ after birth. Data are means \pm s.E.M., $n=$ at least five animals for each genotype; $* P<0 \cdot 05, * * P<0 \cdot 01$.

ketone bodies, and plasma insulin compared with the other two genotypes after birth (Fig. 1). Ir ${ }^{\mathrm{P} 1195 \mathrm{~L} / \mathrm{P} 1195 \mathrm{~L}}$ mice developed hyperglycemia and ketoacidosis and died within 2 days after birth, whereas in $I r^{\mathrm{wt} / \mathrm{wt}}$ and $I r^{\mathrm{P} 1195 \mathrm{~L} / \mathrm{wt}}$ mice body weight was not changed at the extrauterine development (Fig. 2).

\section{Plasma glucose level after i.p. glucose loading}

There were no significant differences between the fasting blood glucose levels of $I r^{\mathrm{wt} / \mathrm{wt}}$ and $I r^{\mathrm{P} 1195 \mathrm{~L} / \mathrm{wt}}$ mice at the ages of 4,12 , and 20 weeks (Fig. 3A). However, the fasting plasma insulin levels in $I^{\mathrm{P} 1195 \mathrm{~L} / \mathrm{wt}}$ mice were much higher than those in $I r^{\mathrm{wt} / \mathrm{wt}}$ mice (Fig. 3B). IPGTTs were performed at age 1620 weeks. The blood glucose level after glucose loading did not show a significant difference between $I r^{\mathrm{wt} / \mathrm{wt}}$ and $I r^{\mathrm{P} 1195 \mathrm{~L} /}$ ${ }^{\text {wt }}$ mice (Fig. 4A), but the plasma insulin level was much higher in $I r^{\mathrm{P} 1195 \mathrm{~L} / \mathrm{wt}}$ mice than in $I r^{\mathrm{wt} / \mathrm{wt}}$ mice (Fig. 4B). The ITTs showed a reduced hypoglycemic response to exogenously administered insulin in $I r^{\mathrm{P} 1195 \mathrm{~L} / \mathrm{wt}}$ mice, compared with that in $I r^{\mathrm{wt} / \mathrm{wt}}$ mice (Fig. $4 \mathrm{C}$ ).

IR expression and its phosphorylation due to the insulin action in $\operatorname{Ir}^{P 1195 L / w t}$ mice

To assess the effects of insulin action on target organs in $I_{r}^{\mathrm{P} 1195 \mathrm{~L} / \mathrm{wt}}$ mice, the regulation of insulin signaling in the liver was examined. The expression level of IR in the liver was reduced by $40 \%$ (Fig. 5A) and insulin-stimulated phosphorylation of IR in the liver was reduced by $80 \%$ in $I_{r}^{\mathrm{P} 1195 \mathrm{~L} / \mathrm{wt}}$ mice, compared with $I r^{\mathrm{wt} / \mathrm{wt}}$ mice (Fig. 5B). There were no significant differences in IRS-1 and IRS-2 protein levels in the livers of $I r^{\mathrm{P} 1195 \mathrm{~L} / \mathrm{wt}}$ and $I r^{\mathrm{wt} / \mathrm{wt}}$ mice, before and after insulin stimulation (Fig. 5C and D). After insulin stimulation, phosphorylation of IRS-1 in the liver decreased by

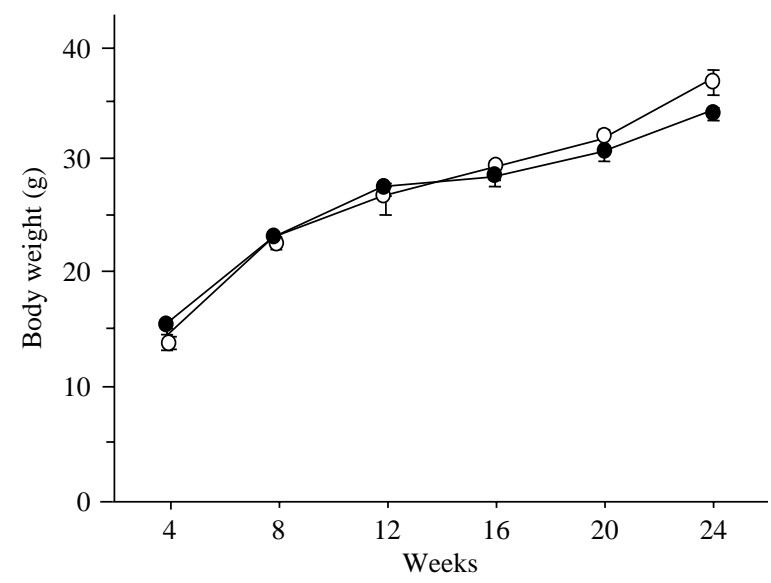

Figure 2 Growth curves showing mean body weight \pm S.E.M. at the indicated ages (weeks). $\bigcirc, I r^{\mathrm{wt} / \mathrm{wt}} ; \boldsymbol{O}, I r^{\mathrm{P} 1195 \mathrm{~L} / \mathrm{wt}} ;$ means \pm S.E.M., $n=$ at least 19 animals for each genotype. 

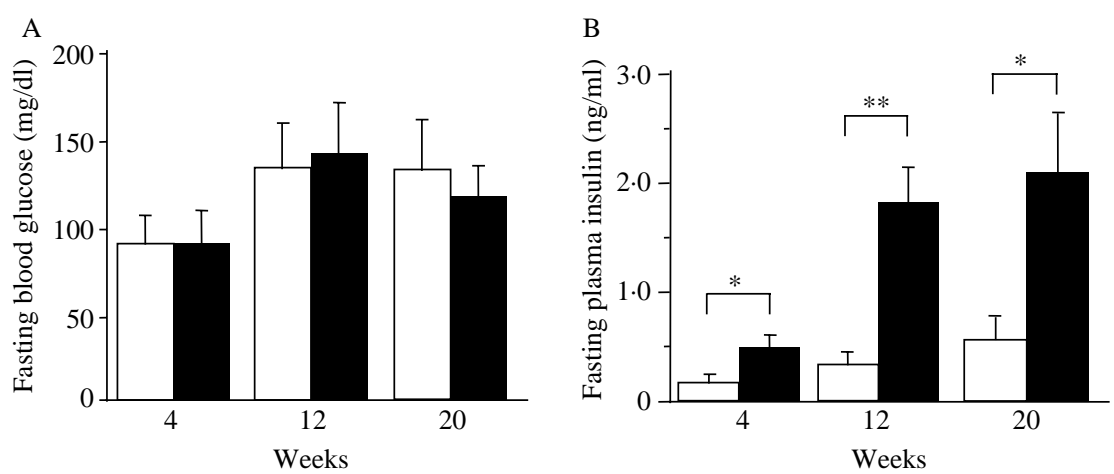

Figure 3 Fasting blood glucose (A) and fasting plasma insulin levels (B) were measured at the ages of 4,12 , and 20 weeks. Open bars, $I r^{\text {wt } / \text { wt. }}$; solid bars, II $r^{\text {1195L/wt; }}$ means \pm S.E.M., $n=7$ animals for each genotype. ${ }^{*} P<0 \cdot 05 ; * * P<0 \cdot 01$.

approximately $40 \%$ in $I r^{\mathrm{P} 1195 \mathrm{~L} / \mathrm{wt}}$ mice, compared with $I r^{\mathrm{wt} / \mathrm{wt}}$ mice (Fig. 5C). In contrast, there was no difference in the insulin-stimulated phosphorylation level of IRS-2 in the livers of $I r^{\mathrm{P} 1195 \mathrm{~L} / \mathrm{wt}}$ and $I r^{\mathrm{wt} / \mathrm{wt}}$ mice (Fig. 5D).

\section{Immunohistochemical analysis of pancreata of $\operatorname{Ir}^{P 1195 L / w t}$ mice}

To investigate the morphological changes in pancreatic islets, immunohistochemical staining of pancreatic sections was performed using an anti-insulin antibody (Fig. 6A). This
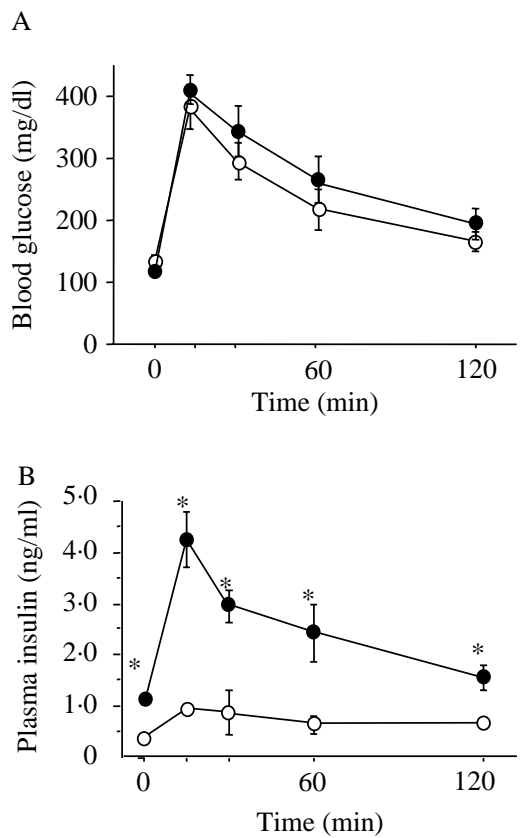

Figure 4 Intraperitoneal glucose tolerance tests were performed at age 16-20 weeks. Mice were fasted overnight, and blood glucose (A) and plasma insulin levels (B) were measured at the indicated times. $O, I^{\mathrm{wt} / \mathrm{wt}} ; \mathbf{O}^{\mathrm{O}}, I^{\mathrm{P} 1195 \mathrm{~L} / \mathrm{wt}} ;$ means \pm S.E.M., $n=9-10$ animals for each genotype; ${ }^{*} P<0 \cdot 05$. Insulin tolerance tests $(C)$ were performed in the fed state at the age of 20 weeks. Results are expressed as percentages of initial blood glucose concentration. $\bigcirc$, $I r^{\mathrm{wt} / \mathrm{wt}} ; \mathbf{O}, I^{\mathrm{P} 1195 \mathrm{~L} / \mathrm{wt}} ;$ means \pm S.E.M., $n=4-5$ animals for each genotype; ${ }^{*} P<0 \cdot 05$. resulted from an increase in the number of $\beta$-cells.

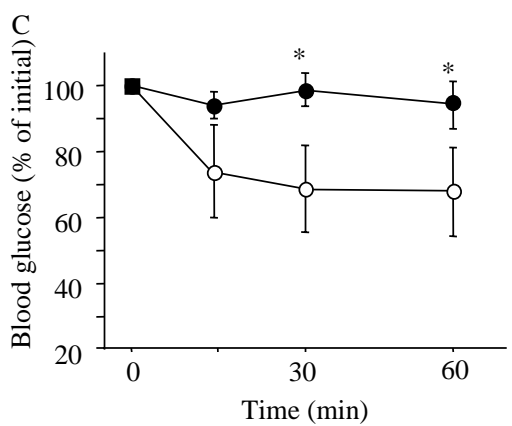

study showed that the $\beta$-cell area per unit area of pancreas in $I_{r}^{\mathrm{P} 1195 \mathrm{~L} / \mathrm{wt}}$ mice was approximately fourfold that in $I r^{\mathrm{wt} / \mathrm{wt}}$ mice (Fig. 6B). The number of islet $\beta$-cells per unit area of pancreas was increased in $I r^{\mathrm{P} 1195 \mathrm{~L} / \mathrm{wt}}$ mice (Fig. 6C), but the calculated $\beta$-cell size did not differ between $I r^{\mathrm{wt} / \mathrm{wt}}$ and $I r^{\mathrm{P} 1195 \mathrm{~L} / \mathrm{wt}}$ mice (Fig. 6D). The weight of pancreatic tissues was not significantly different between $I r^{\mathrm{wt} / \mathrm{wt}}$ and $I r^{\mathrm{P} 1195 \mathrm{~L} / \mathrm{wt}}$ mice at 8 weeks of age $\left(I^{\mathrm{wt} / \mathrm{wt}}, 0 \cdot 122 \pm 0 \cdot 028 \mathrm{~g} ; I^{\mathrm{P} 1195 \mathrm{~L} / \mathrm{wt}}, 0 \cdot 138 \pm 0 \cdot 049 \mathrm{~g}\right)$. These data suggest that the increased $\beta$-cell mass in $I_{r}^{\mathrm{P} 1195 \mathrm{~L} / \mathrm{wt}}$ mice 
A

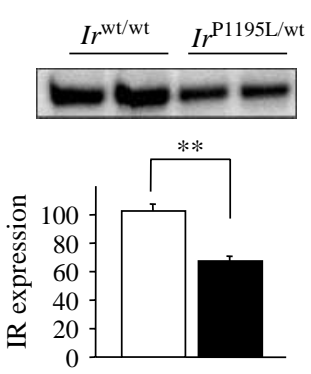

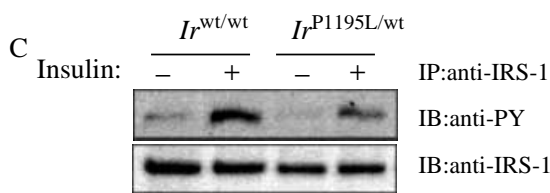

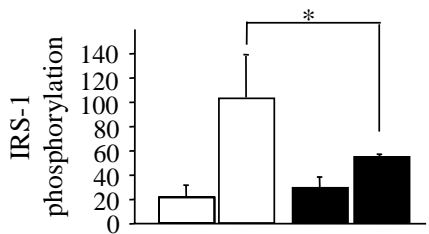

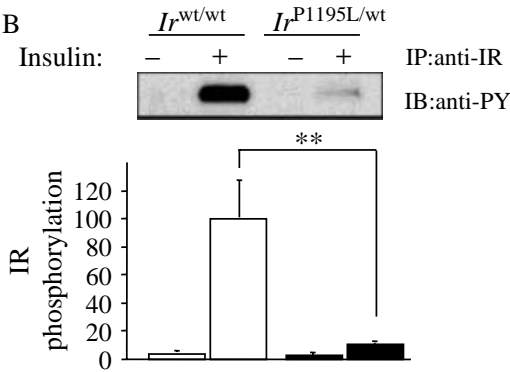

$\begin{array}{cll}\mathrm{D} \text { Insulin: } & \frac{I r^{\mathrm{wt} / \mathrm{wt}}}{-}+\frac{I r^{\mathrm{P} 1195 \mathrm{~L} / \mathrm{wt}}}{-+} & \\ & \text { IP:anti-IRS-2 } \\ & \text { IB:anti-PY } \\ & \text { IB:anti-IRS-2 }\end{array}$

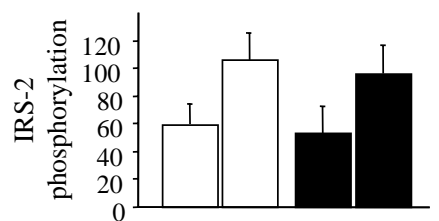

Figure 5 Expression of IR in the liver (A), and insulin-stimulated phosphorylation of IR (B), IRS-1 (C), and IRS-2 (D) in the liver. Mice were fasted overnight and then injected i.p. with either saline ( - ) or insulin (+). Equal amounts of protein from the liver were immunoprecipitated (IP) with anti-IR (A and B), anti-IRS-1 (C), or anti-IRS-2 (D) antibody, and immunoblotted (IB) with anti-IR (A), antiphosphotyrosine (anti-PY) (B, C and D), anti-IRS-1 (C), or anti-IRS-2 (D) antibody. Each upper panel shows a representative blot and the lower panel shows the quantification of the results. Open bars, $I r^{\text {wt/wt. }}$; solid bars, $I r^{\text {P1195L/wt; }}$ means \pm S.E.M., $n=3$ animals for each genotype; $* P<0 \cdot 05 ; * * P<0 \cdot 01$.

\section{Pancreatic $\beta$-cell proliferation and apoptosis}

To determine the cause of the increased $\beta$-cell mass in $\operatorname{Ir}^{\mathrm{P} 1195 \mathrm{~L} / \mathrm{wt}}$ mice, $\beta$-cell proliferation and apoptotic susceptibility were investigated. The number of BrdU and insulin double-positive cells expressed as a percentage of the total number of insulinpositive cells increased in islets of $\operatorname{Ir}^{\mathrm{P} 1195 \mathrm{~L} / \mathrm{wt}}$ mice, compared with those of $I r^{\mathrm{wt} / \mathrm{wt}}$ mice (Fig. 7A), whereas the percentage of TUNEL and insulin double-positive cells in the total number of insulin-positive cells was not significantly different between $I r^{\mathrm{wt} / \mathrm{wt}}$ and $I r^{\mathrm{P} 1195 \mathrm{~L} / \mathrm{wt}}$ mice before streptozotocin (STZ) administration (Fig. 7C). To confirm that the two mice genotypes were equally susceptible to $\beta$-cell apoptosis, their responses to STZ were analyzed. After STZ administration, both genotypes showed the same level of plasma glucose (Fig. 7B). The number of TUNEL-positive $\beta$-cells after STZ administration did not differ significantly between $I r^{\mathrm{wt} / \mathrm{wt}}$ and $I^{\mathrm{P} 1195 \mathrm{~L} / \mathrm{wt}}$ mice (Fig. 7C).

\section{Discussion}

Insulin signaling plays an important role in the metabolism and growth of insulin target cells. Insulin acts through a signaling cascade that involves a number of molecules, including the IR,
IRSs, phosphoinositide 3-kinase (PI3K), and Akt/protein kinase $\mathrm{B}(\mathrm{PKB})$. The tyrosine kinase domain of the $\mathrm{IR}$ is initially phosphorylated by insulin binding and greatly augmented by insulin-stimulated autophosphorylation (White \& Kahn 1994). Various mutations in the IR gene have been identified in human subjects (Taira et al. 1989, Shimada et al. 1990, Suzuki et al. 1991, Tritos \& Mantzoros 1998), and some patients with a mutation in the tyrosine kinase domain of the IR $\beta$-subunit show hyperinsulinemia and insulin resistance. Alterations in the IR gene result in varying degrees of glucose homeostasis. Normal glucose tolerance is maintained as long as $\beta$-cells can secrete a sufficient amount of insulin against augmented insulin resistance. However, when insulin secretion in response to insulin resistance fails, glucose homeostasis breaks down.

To analyze the insulin-signaling pathways, several transgenic, and knockout mice bearing mutations in proteins which transmit the insulin signal have been generated. Mice heterozygous for IR $\left(I R^{+/-}\right)$(Bruning et al. 1997, Kido et al. 2000), IRS-1 knockout (IRS-1 ${ }^{-/-}$) mice (Araki et al. 1994, Tamemoto et al. 1994), young IR/IRS-1 double heterozygous $\left(I R^{+/-} / I R S-1^{+/-}\right)$mice (Bruning et al. 1997) and Akt2/PKB $\beta$-knockout $\left(A k t 2 / P K B \beta^{-/-}\right)$mice (Cho et al. 2001) all display insulin resistance and islet hyperplasia. 
A
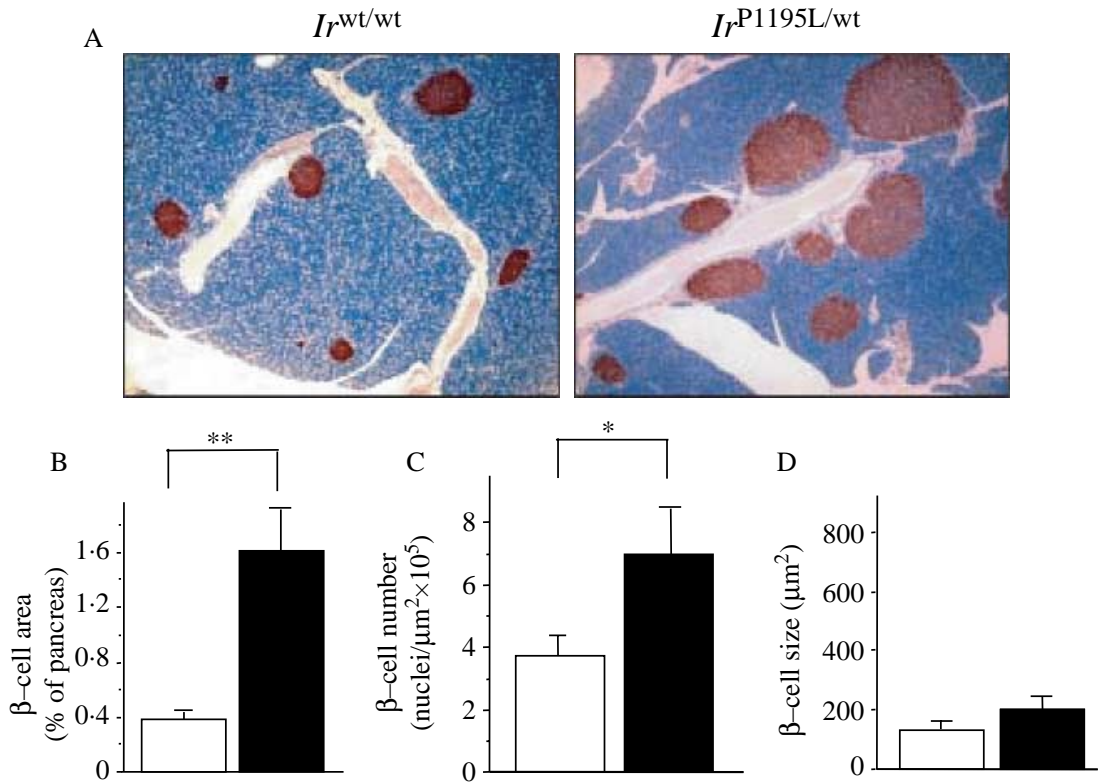

Figure 6 Pancreatic sections at age 20 weeks were immunostained for insulin and photographed at a magnification of $\times 50$. Representative islets from each genotype are shown (A). Results are expressed as the percentage of $\beta$-cells over the total pancreatic area (B) and as the $\beta$-cell number over the total pancreatic area (C). $\beta$-Cell size is expressed as the total $\beta$-cell area per number of $\beta$-cell nuclei (D). Open bars, $I r^{\mathrm{wt} / \mathrm{wt}}$; solid bars, II ${ }^{\mathrm{P} 1195 \mathrm{~L} / \mathrm{wt}}$; means \pm S.E.M., $n=3$ animals for each genotype; ${ }^{*} P<0 \cdot 05,{ }^{* *} P<0 \cdot 01$.

Glucose tolerance in these mice is normal or mildly impaired, suggesting that over-secretion of insulin maintains normal glucose homeostasis or keeps deterioration to a minimum. Hence, these phenotypes are similar to those of $I r r^{\mathrm{P} 1195 \mathrm{~L} / \mathrm{wt}}$ mice. Baba et al. (2005) have previously reported that male Ir $^{\mathrm{P} 1195 \mathrm{~L} / \mathrm{wt}}$ mice show mildly impaired glucose tolerance, while our $I_{r}^{\mathrm{P} 1195 \mathrm{~L} / \mathrm{wt}}$ mice had a normal level of plasma glucose after glucose loading; this difference may be due to different chow used in the two laboratories. The mechanism of insulin hypersecretion is not completely understood, but may be explained by the increased insulin secretion of individual $\beta$-cells and/or an increased number of $\beta$-cells. It has been reported that the pancreatic $\beta$-cell mass is increased in $I R^{+/-}, I R S-1^{-/-}$, $I R^{+/-} / I R S-1^{+/-}$, and $A k t 2 / P K B \beta^{-1-}$ mice (Araki et al. 1994, Bruning et al. 1997, Cho et al. 2001), and it has also been reported that there is a reduction in insulin content and insulin secretion normalized by cell number per islet in $I R S-1^{-1-}$ mice compared with $I r^{\mathrm{wt} / \mathrm{wt}}$ mice (Kubota et al. 2000). Therefore, an increased $\beta$-cell number may be more important for maintaining insulin content and insulin secretion, rather than the hyperfunction of each $\beta$-cell. Analyses of insulin content and insulin secretion of individual $\beta$-cells have not been performed in $I r r^{\mathrm{P} 1195 \mathrm{~L} / \mathrm{wt}}$ mice. The same histological features and similar phenotypes to those of IRS-1 $1^{-1-}$ mice were observed in $I_{r}^{\mathrm{P} 1195 \mathrm{~L} / \mathrm{wt}}$ mice, and therefore increased $\beta$-cell number, rather than the hyperfunction of individual $\beta$-cells, may be responsible for increased insulin secretion in response to insulin resistance in $I_{r}^{\mathrm{P} 1195 \mathrm{~L} / \mathrm{wt}}$ mice.
Islet $\beta$-cell mass is maintained by a balance of $\beta$-cell proliferation and apoptosis (Flier et al. 2001). In $\operatorname{Ir}^{\mathrm{P} 1195 \mathrm{~L} / \mathrm{wt}}$ mice, $\beta$-cell mass increased and $\beta$-cell proliferation accelerated, but $\beta$-cell apoptosis was not suppressed. Hence, increased $\beta$-cell proliferation, rather than decreased $\beta$-cell apoptosis, is the primary cause of the increase in $\beta$-cell mass in $I_{r}^{\mathrm{P} 1195 \mathrm{~L} / \mathrm{wt}}$ mice. However, the mechanism of the increasing $\beta$-cell proliferation also remains unknown.

One possible mechanism of $\beta$-cell proliferation is the stimulation of the insulin-like growth factor-I (IGF-I) receptor/IRS-2 axis. Studies of IRS-2 knockout (IRS-2 $\left.{ }^{-\prime-}\right)$ mice have shown that IRS-2 plays an important role in the regulation of the $\beta$-cell mass (Withers et al. 1998), and IGF-I receptors have been reported to promote $\beta$-cell development and survival through the IRS-2 signaling pathway (Withers et al. 1999, Lingohr et al. 2002b). Transgenic mice overexpressing IGF-I in $\beta$-cells are protected from STZ-induced $\beta$-cell apoptosis (George et al. 2002), and transgenic mice expressing a constitutively active form of Akt $1 / \mathrm{PKB} \alpha$ in $\beta$-cells (Bernal-Mizrachi et al. 2001, Tuttle et al. 2001), show a significant increase in both $\beta$-cell size and total islet mass, accompanied with improved glucose tolerance and protection against $\beta$-cell apoptosis following STZ treatment. Akt is located downstream of IRSs and is a major target of PI3K. Hence, these data suggest that activation of IGF-I signaling, through IRS-2, is a key element in the regulation and proliferation of $\beta$-cells, and protects islet $\beta$-cells from apoptosis after STZ loading. 

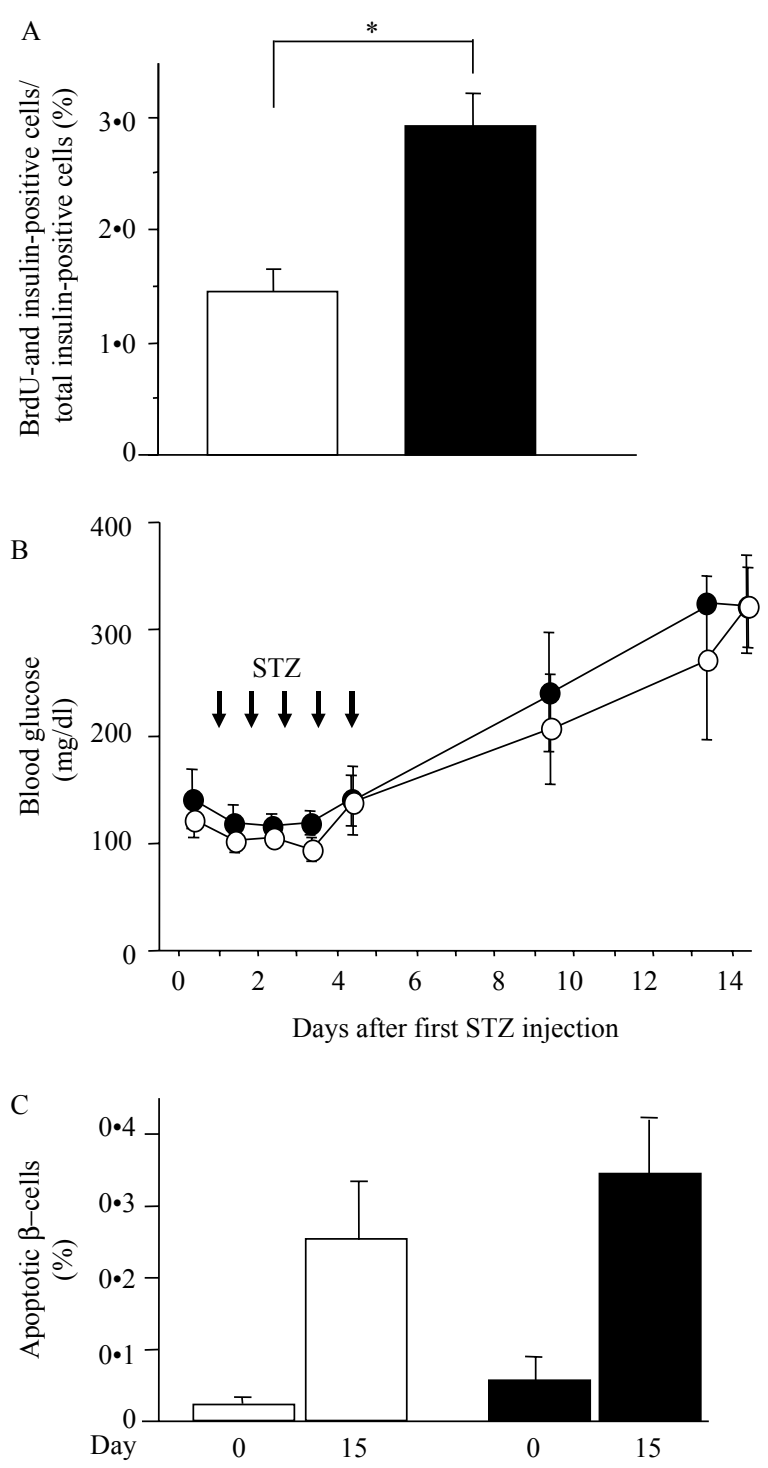

Figure $7 \mathrm{BrdU}$ incorporation at 4 weeks of age (A). Pancreatic sections were stained with anti-BrdU and anti-insulin antibodies. Data are shown as the number of BrdU- and insulin-positive cells expressed as a percentage of the total number of insulin-positive cells $(\%)$. Open bars, $I r^{\mathrm{wt} / \mathrm{wt}}$; solid bars, $I r^{\mathrm{P} 1195 \mathrm{~L} / \mathrm{wt}}$; means \pm s.E.M., $n=3$ animals for each genotype; $* P<0 \cdot 05$. Blood glucose levels are shown at the indicated time after STZ administration (B). $\bigcirc$, $I r^{\mathrm{wt} / \mathrm{wt}} ; 0, r^{\mathrm{P} 1195 \mathrm{~L} / \mathrm{wt}} ;$ means \pm s.E.M., $n=5$ animals for each genotype. Detection of $\beta$-cell apoptosis using the TUNEL assay at the age of 8 weeks (C). Data are shown as the percentage of TUNEL and insulin double-positive cells in the total number of $\beta$ cells (\%). Open bars, $I r^{\mathrm{wt} / \mathrm{wt}}$; solid bars, $I r^{\mathrm{P} 1195 \mathrm{~L} / \mathrm{wt}} ;$ means \pm s.E.M., $n=5$ animals for each genotype.

It has been reported that high concentration insulin stimulates IGF-I receptor (Entingh-Pearsall \& Kahn 2004, $\mathrm{Li}$ et al. 2005). In $\operatorname{Ir}^{\mathrm{P} 1195 \mathrm{~L} / \mathrm{wt}}$ mice, it is possible that elevated plasma insulin binds to IGF-I receptors in pancreatic $\beta$-cells and stimulates $\beta$-cell proliferation through IRS-2 phosphorylation. We attempted to evaluate the expression and phosphorylation levels of IRS-2 in the liver. In $I r^{\mathrm{P} 1195 \mathrm{~L} / \mathrm{wt}}$ mice, there was no elevation of expression levels or phosphorylation levels of IRS-2 in the liver before and after insulin administration, but the pancreatic $\beta$-cell mass was larger than that in $I r^{\mathrm{wt} / \mathrm{wt}}$ mice. The same results have been reported in $I R^{+/-}$, IRS $-1^{+/-}$mice (Bruning et al. 1997). Hence, elevated insulin may not increase IRS-2 phosphorylation in $\beta$-cells in $I^{\mathrm{P} 1195 \mathrm{~L} / \mathrm{wt}}$ and $I R^{+/-} / I R S-1^{+/-}$mice, suggesting that IRS-2 is not an essential molecule for increased $\beta$-cell proliferation in these mice. In $\operatorname{Ir}^{\mathrm{P} 1195 \mathrm{~L} / \mathrm{wt}}$ mice, the level of IRS-1 phosphorylation mildly decreased, IRS-2 phosphorylation was unaffected, and IR phosphorylation was severely decreased, compared with $I r^{\mathrm{wt} / \mathrm{wt}}$ mice. Phosphorylation of IRS-1 and IRS-2 may be regulated by factors other than insulin, including growth hormone, IGF-I, interferon- $\alpha$ and $\gamma$, prolactin, and cytokine signaling (Argetsinger et al. 1995, 1996, Uddin et al. 1995, Bole-Feysot et al. 1998, Kulkarni et al. 2002), and these factors may cause differences in phosphorylation levels between IR and IRSs. In $\operatorname{Ir}^{\mathrm{P} 1195 \mathrm{~L} / \mathrm{wt}}$ mice, $\beta$-cell proliferation was accelerated, but $\beta$-cell apoptosis was not suppressed. Furthermore, although STZ treatment increased the number of apoptotic cells, the effects of STZ were similar in $I r^{\mathrm{wt} / \mathrm{wt}}$ and $I r^{\mathrm{P} 1195 \mathrm{~L} / \mathrm{wt}}$ mice. These data suggest that $I r^{\mathrm{P} 1195 \mathrm{~L} / \mathrm{wt}}$ mice are not resistant to STZ-induced diabetes, and cannot protect $\beta$-cells from apoptosis. This result differs from previous studies of stimulation of the IGF-I receptor/IRS-2 signaling such as transgenic mice overexpressing IGF-I in $\beta$-cells and those expressing constitutively active $\mathrm{Akt} 1 / \mathrm{PKB} \alpha$ in $\beta$-cells, suggesting that the increased $\beta$-cell mass does not result from activated IGF-I receptor/IRS-2 signaling in Ir $^{\mathrm{P} 1195 \mathrm{~L} / \mathrm{wt}}$ mice.

It has been reported that islet $\beta$-cell-specific IGF-I receptor knockout ( $\beta I G F R K O)$ mice did not show a significant dissimilarity in $\beta$-cell mass, compared with wild-type mice (Kulkarni et al. 2002). These data suggest that the IGF-I receptor is not crucial for islet $\beta$-cell development, supporting the hypothesis that IGF-I signaling is not involved in the increase in $\beta$-cells in $\operatorname{Ir}^{\mathrm{P} 1195 \mathrm{~L} / \mathrm{wt}}$ mice. Other possible signaling pathways that are independent of IGF-I receptor, such as those of prolactin (Bole-Feysot et al. 1998) and leptin (Tanabe et al. 1997), may play a role in $\beta$-cell proliferation. These growth factors were not measured in this study, and further work is necessary to determine the specific growth factors directly associated with $\beta$-cell proliferation.

In conclusion, Ir ${ }^{\mathrm{P} 1195 \mathrm{~L} / \mathrm{wt}}$ mice had almost normal glucose tolerance, but showed hyperinsulinemia in response to insulin resistance. An increased number of $\beta$-cells may have accommodated the increased insulin requirement. Signaling through IGF-I receptor/IRS-2 was not considered to be the main pathway for islet $\beta$-cell 
proliferation, and other signals that are independent of the IGF-I receptor/IRS-2 pathway may influence increased proliferation. Since $I r^{\mathrm{P} 1195 \mathrm{~L} / \mathrm{wt}}$ mice have a similar phenotype to patients with mutations of the IR tyrosine kinase domain, this animal model could be useful for the analysis of the physiology in these patients. Such studies may allow elucidation of the mechanism of $\beta$-cell proliferation and identification of the $\beta$-cell growth factors.

\section{Acknowledgements}

The authors thank Mrs K Amano for technical assistance. The authors declare that there is no conflict of interest that would prejudice the impartiality of this scientific work.

\section{References}

Argetsinger LS, Hsu GW, Myers MGJr., Billestrup N, White MF \& Carter-Su C 1995 Growth hormone, interferon-gamma, and leukemia inhibitory factor promoted tyrosyl phosphorylation of insulin receptor substrate-1. Journal of Biological Chemistry 270 14685-14692.

Argetsinger LS, Norstedt G, Billestrup N, White MF \& Carter-Su C 1996 Growth hormone, interferon-gamma, and leukemia inhibitory factor utilize insulin receptor substrate-2 in intracellular signaling. Journal of Biological Chemistry 271 29415-29421.

Araki E, Lipes MA, Patti ME, Bruning JC, Haag B 3rd., Johnson RS \& Kahn CR 1994 Alternative pathway of insulin signalling in mice with targeted disruption of the IRS-1 gene. Nature 372 186-190.

Baba T, Shimizu T, Suzuki Y, Ogawara M, Isono K, Koseki H, Kurosawa H \& Shirasawa T 2005 Estrogen, insulin, and dietary signals cooperatively regulate longevity signals to enhance resistance to oxidative stress in mice. Journal of Biological Chemistry 280 16417-16426.

Bernal-Mizrachi E, Wen W, Stahlhut S, Welling CM \& Permutt MA 2001 Islet beta cell expression of constitutively active Akt1/PKB alpha induces striking hypertrophy, hyperplasia, and hyperinsulinemia. Journal of Clinical Investigation 108 1631-1638.

Bole-Feysot C, Goffin V, Edery M, Binart N \& Kelly PA 1998 Prolactin $(\mathrm{PRL})$ and its receptor: actions, signal transduction pathways and phenotypes observed in PRL receptor knockout mice. Endocrine Reviews $19225-268$.

Bruning JC, Winnay J, Bonner-Weir S, Taylor SI, Accili D \& Kahn CR 1997 Development of a novel polygenic model of NIDDM in mice heterozygous for IR and IRS-1 null alleles. Cell 88 561-572.

Bruning JC, Michael MD, Winnay JN, Hayashi T, Horsch D, Accili D, Goodyear LJ \& Kahn CR 1998 A muscle-specific insulin receptor knockout exhibits features of the metabolic syndrome of NIDDM without altering glucose tolerance. Molecular Cell 2 559-569.

Cho H, Mu J, Kim JK, Thorvaldsen JL, Chu Q, Crenshaw EB 3rd, Kaestner KH, Bartolomei MS, Shulman GI \& Birnbaum MJ 2001 Insulin resistance and a diabetes mellitus-like syndrome in mice lacking the protein kinase Akt2 (PKB beta). Science 292 1728-1731.

DeFronzo RA, Bonadonna RC \& Ferrannini E 1992 Pathogenesis of NIDDM. A balanced overview. Diabetes Care 15 318-368.

Entingh-Pearsall A \& Kahn CR 2004 Differential roles of the insulin and insulin-like growth factor-I (IGF-I) receptors in response to insulin and IGF-I. Journal of Biological Chemistry 279 38016-38024.

Flier SN, Kulkarni RN \& Kahn CR 2001 Evidence for a circulating islet cell growth factor in insulin-resistant states. PNAS 98 7475-7480.

George M, Ayuso E, Casellas A, Costa C, Devedjian JC \& Bosch F 2002 Beta cell expression of IGF-I leads to recovery from type 1 diabetes. Journal of Clinical Investigation 109 1153-1163.
Kido Y, Burks DJ, Withers D, Bruning JC, Kahn CR, White MF \& Accili D 2000 Tissue-specific insulin resistance in mice with mutations in the insulin receptor, IRS-1, and IRS-2. Journal of Clinical Investigation 105 199-205.

Kim H, Kadowaki H, Sakura H, Odawara M, Momomura K, Takahashi Y, Miyazaki Y, Ohtani T, Akanuma Y, Yazaki Y et al. 1992 Detection of mutations in the insulin receptor gene in patients with insulin resistance by analysis of single-stranded conformational polymorphisms. Diabetologia 35 261-266.

Kubota N, Tobe K, Terauchi Y, Eto K, Yamauchi T, Suzuki R, Tsubamoto Y, Komeda K, Nakano R, Miki H et al. 2000 Disruption of insulin receptor substrate 2 causes type 2 diabetes because of liver insulin resistance and lack of compensatory beta-cell hyperplasia. Diabetes $\mathbf{4 9}$ 1880-1889.

Kulkarni RN, Bruning JC, Winnay JN, Postic C, Magnuson MA \& Kahn CR 1999 Tissue-specific knockout of the insulin receptor in pancreatic beta cells creates an insulin secretory defect similar to that in type 2 diabetes. Cell 96 329-339.

Kulkarni RN, Holzenberger M, Shih DQ, Ozcan U, Stoffel M, Magnuson MA \& Kahn CR 2002 Beta-cell-specific deletion of the IGF1 receptor leads to hyperinsulinemia and glucose intolerance but does not alter beta-cell mass. Nature Genetics 31 111-115.

Li G, Barrett EJ, Wang H, Chai W \& Liu Z 2005 Insulin at physiological concentrations selectively activates insulin but not insulin-like growth factor I (IGF-I) or insulin/IGF-I hybrid receptors in endothelial cells. Endocrinology 146 4690-4696.

Lingohr MK, Buettner R \& Rhodes CJ 2002a Pancreatic beta-cell growth and survival - a role in obesity-linked type 2 diabetes? Trends in Molecular Medicine 8 375-384.

Lingohr MK, Dickson LM, McCuaig JF, Hugl SR, Twardzik DR \& Rhodes CJ $2002 b$ Activation of IRS-2-mediated signal transduction by IGF-1, but not TGF-alpha or EGF, augments pancreatic beta-cell proliferation. Diabetes 51 966-976.

Michael MD, Kulkarni RN, Postic C, Previs SF, Shulman GI, Magnuson MA \& Kahn CR 2000 Loss of insulin signaling in hepatocytes leads to severe insulin resistance and progressive hepatic dysfunction. Molecular Cell 6 87-97.

Nandi A, Kitamura Y, Kahn CR \& Accili D 2004 Mouse models of insulin resistance. Physiological Reviews 84 623-647.

Reaven GM 1988 Banting lecture. Role of insulin resistance in human disease. Diabetes 37 1595-1607.

Shibasaki M, Takahashi K, Itou T, Bujo H \& Saito Y 2003 A PPAR agonist improves TNF-alpha-induced insulin resistance of adipose tissue in mice. Biochemical and Biophysical Research Communications 309 419-424.

Shimada F, Taira M, Suzuki Y, Hashimoto N, Nozaki O, Tatibana M, Ebina Y, Tawata M, Onaya T, Makino H et al. 1990 Insulin-resistant diabetes associated with partial deletion of insulin-receptor gene. Lancet 335 1179-1181.

Suzuki Y, Hashimoto N, Shimada F, Taira M, Mimura M, Nozaki O, Tawata M, Onaya T, Makino H \& Yoshida S 1991 Defects in insulin binding and receptor kinase in cells from a woman with type A insulin resistance and from her family. Diabetologia 34 86-92.

Taira M, Hashimoto N, Shimada F, Suzuki Y, Kanatsuka A, Nakamura F, Ebina Y, Tatibana M, Makino H \& Yoshida S 1989 Human diabetes associated with a deletion of the tyrosine kinase domain of the insulin receptor. Science 245 63-66.

Tamemoto H, Kadowaki T, Tobe K, Yagi T, Sakura H, Hayakawa T, Terauchi Y, Ueki K, Kaburagi Y, Satoh S et al. 1994 Insulin resistance and growth retardation in mice lacking insulin receptor substrate-1. Nature 372 182-186.

Tanabe K, Okuya S, Tanizawa Y, Matsutani A \& Oka Y 1997 Leptin induces proliferation of pancreatic beta cell line MIN6 through activation of mitogen-activated protein kinase. Biochemical and Biophysical Research Communications 241 765-768.

Tritos NA \& Mantzoros CS 1998 Clinical review 97: syndromes of severe insulin resistance. Journal of Clinical Endocrinology and Metabolism $\mathbf{8 3}$ 3025-3030. 
Tuttle RL, Gill NS, Pugh W, Lee JP, Koeberlein B, Furth EE, Polonsky KS, Naji A \& Birnbaum MJ 2001 Regulation of pancreatic beta-cell growth and survival by the serine/threonine protein kinase Akt1/PKBalpha. Nature Medicine 7 1133-1137.

Uddin S, Yenush L, Sun XJ, Sweet ME, White MF \& Platanias LC 1995 Interferon-alpha engages the insulin receptor substrate-1 to associate with the phosphatidylinositol 3'-kinase. Journal of Biological Chemistry 270 15938-15491.

White MF \& Kahn CR 1994 The insulin signaling system. Journal of Biological Chemistry 269 1-4.

Withers DJ, Gutierrez JS, Towery H, Burks DJ, Ren JM, Previs S, Zhang Y, Bernal D, Pons S, Shulman GI et al. 1998 Disruption of IRS-2 causes type 2 diabetes in mice. Nature $391900-904$
Withers DJ, Burks DJ, Towery HH, Altamuro SL, Flint CL \& White MF 1999 IRS-2 coordinates IGF-1 receptor-mediated beta-cell development and peripheral insulin signalling. Nature Genetics 23 32-40.

Received 2 March 2006

Received in final form 26 April 2006

Accepted 11 May 2006

Made available online as an Accepted Preprint 14 June 2006 